\title{
Command Agriculture: Local Knowledge and External Development Models in Rural Zimbabwe-The Case of the Makwe Irrigation Scheme.
}

\author{
Dr. Clifford Mabhena \\ National University of Science and Technology-Institute of Development Studies
}

\begin{abstract}
Command agriculture is a rural development strategy adopted by the Zimbabwe government as one of several strategies in its broad land reform policy framework. It was said to be geared toward increasing cereal production to boost national food reserves. The army championed this programme. This agricultural model targeted irrigation schemes nationwide. Command agriculture was planned and implemented without consultation with irrigation plot holders, and in this study, specifically the Makwe community. Using the case study approach I conducted a series of interviews between 2005 and 2006 to ascertain the implications of this land husbandry model to livelihoods of Makwe irrigators. The 'command' style the army arrived at Makwe caused some shocks and stresses to plot holders whose market gardening was destroyed by the army to pave way for cereal farming. The arrival of soldiers turned this lucrative venture and a source of livelihoods for Makwe plot holders; and villagers of Lushongwe and Wenlock, into a "collective" whereby the former farmed the irrigation rather than their individual plots in this scheme. Command agriculture is thus viewed as one of those top down rural development models that fail to recognize local knowledge in development planning.
\end{abstract}

\section{Introduction}

"If you are to suffer, you should suffer in the interest of your country"; Jawaharlal Nehru, Indian Prime Minister speaking to villagers who were to be displaced by the giant Hirakud Dam in 1948. What do these words mean to Makwe villagers; was command agriculture (Operation Maguta) the best option for their livelihoods? Did they ask for state intervention in their production circle? Don't they possess the knowledge, capabilities; and technical advice necessary to farm the irrigation without the watchful eyes of soldiers? Were soldiers a productive power in Makwe irrigation scheme? Cohen views productive powers as anything that can be used in productive interaction with nature. To qualify as productive power, "a facility must be capable of use by a producing agent in such a way that production occurs (partly) as a result of its use, and it is someone's purpose that the facility so contribute to production ${ }^{1}$ Was it the case at Makwe irrigation scheme? Be it in the community or market realm of economy, Marxists argue that means of production will only realize a product only if men/women summon their live labour power for production to take place.

In this article, I explore the impacts of "command agriculture" dubbed 'operation Maguta'-Eat well, on Makwe irrigators and the surrounding communities. I conducted research in this area from October 2005 to May 2006. Using in-depth interviews, over twenty irrigators were interviewed on issues pertaining to their life histories, land, livelihoods and rural development. In the middle of my ethnography, in December 2005, the government launched "operation Maguta", which brought in a completely new system of irrigation farming nationwide. In short, the operation entailed that all irrigation schemes grow staple maize and winter wheat to boost government stocks. As part of field observation and interaction with the Makwe community; I witnessed the inception of the operation and later on interviewed the chairperson of the irrigation committee and some irrigators. They gave heart breaking experiences of the operation and its short term and long term effects on irrigation development; let alone way of life of Makwe villagers and the Wenlock community.

I therefore attempt to answer the following question: Was command agriculture the best option of utilizing irrigable land in semi arid regions for people to sustain their livelihoods? From field work data and reviewed literature, I argue that command agriculture brought shocks and stresses to the Makwe villagers and hence a 'top - down' land reform policy. In this article, attention is paid to external development models and local knowledge, the role of the military in Matabeleland since independence, the nationalization of irrigation schemes with particular emphasis on Makwe. I also explore, using primary and secondary data, short term and long term impacts of command agriculture on Makwe plot holders' livelihoods and those of their kinsmen in

\footnotetext{
${ }^{1} 1$. Donham (1990:59) cites Cohen who points out, the phrase 'productive powers' also has its problems. Strictly speaking, we cannot say a tool is a productive power, rather it has such power when put in motion by a human being
} 
adjacent Wenlock communal areas. Note that I will use the terms command agriculture and operation Maguta interchangeably.

\section{Perspectives of External Development Models in Rural Zimbabwe}

Since independence in 1980, Zimbabwe has experimented on various development models focusing on poverty reduction and improvement of rural people's living standards. Development has been conceived by Cormac (1989) as multi-dimensional and involves changes in structure, attitudes and institutions. It is the acceleration of economic growth, the reduction of inequality and the eradication of poverty. Rodney (1972) views development as implying increased skill and capacity, greater freedom, creativity, self discipline, responsibility and material well being. In Zimbabwe today about $80 \%$ of the population resides in rural areas, hence focus of government and NGOs has been on rural development. Harris (1982) noted that rural development is a process that aims at improving the living standards of the rural people. The process is multifaceted since it focuses on the economic, social and physical aspects of the people. (See also Chambers 1983; Scoones and Wolmer 2003).

In more recent times, rural development policy has been constructed around a particular narrative centred on assumed efficiency of the small family farm. Agriculture as the mainstay of rural economy in Southern Africa, can, it is argued, be transformed through technology transfer, supported by effective extension services, input supply and credit systems (Scoones and Wolmer, 2003). The use of agriculture as an economic engine has been stifled in recent years in Zimbabwe by the controversial Fast Track Land Reform Programme (FTLRP).

With the above sentiments, rural communities have been caught in the rubric of development models. For instance Scoones wrote about the pro-poor growth, the private sector markets, decentralization and the rights based approaches ${ }^{2}$ Orr and Mwale, when examining livelihood strategies of smallholder farmers in Malawi during Economic Structural Adjustment programme contended that agricultural intensification and livelihood diversification had the greatest impact on improving smallholder incomes.

The integrated approach is one of the development strategies that has been adopted by the Zimbabwe government since independence. A number of programmes and projects aimed at improving the life of the rural poor had been modeled along this line of thought. The major aim of the Integrated Rural Development strategy was to reduce poverty and improve rural people's lives. It also envisaged integrated planning and skills development ${ }^{3}$. According to the Matabeleland South Provincial Poverty Reduction Plan (2005-2015), there is very close relationship between poverty and development or lack of it. Most of the development initiatives have been designed with the express purpose of trying to eradicate poverty or at least reduce it. However, most of these initiatives have failed because they have not addressed the core issue of the meaningful involvement of the people who are afflicted by poverty. The interventions have also failed to recognize the very pivotal role that individuals and communities play in the alleviation of poverty. As a result the communities have been regarded as nothing more than passive beneficiaries of development projects. Does this observation have a link with the introduction of "operation Maguta" in Makwe irrigation scheme? This question is answered in due course.

Command agriculture is a new concept in Zimbabwe that borrows heavily from the Maoist-Stalinist command economy. Verdery, 2003; cites Marx and Engels (1968:3), the theory of communists...is the abolition of private property. Frydman and Rpaczynski (1994:11) noted that socialist economies did not have any property system...governing their productive activities...the legal determination of ownership was simply irrelevant under the old system which relied instead on directly prescribing the conduct of factory workers. Verdery further argued that, land became socialist property through nationalization/confistication and collectivization (Verdery, 2003:41). At the height of collectivization in Romania, members were ordered to surrender their land to the collective and the boundary paths separating land parcels were abolished; the terrain of the farm was divided into fields according to the rotation adopted and was to be worked in common by collective members. Collectivization was not a smooth and straight forward affair; Verdery noted that people were forced into these collectives through arrests, beatings or even being killed.

Research, done for the Matabeleland South ten year plan, revealed that the lack of organizational capacity by service providers (integration), has affected service delivery, and this has created a dependency syndrome among the rural poor. On this note, the culture of looking for external support at the expense of local initiatives has been ingrained amongst people, leaving them as bystanders in the development process. Is this the case with Makwe plot holders? Local knowledge cannot be overemphasized in any rural development initiatives let alone in social transformation. Though communities are poor, I argue that communities do have internal coping mechanisms. These mechanisms manifest themselves in the way people survive on the little they have. Rural people engage in self employment activities such as cross border trading, income generating projects, gold

. Scoones and Wolmer (2003), Perspectives on governance: implications for a sustainable livelihoods approach

. First five year National Development plan Volume 2, 1984 
panning and market gardening for survival. Through social networks and kinship relations, rural people survive also on remittances and selling of their livestock when they feel it's necessary to off set a problem. In Makwe for instance, irrigators would "share" what ever produce they get with their kinsmen in Wenlock communal lands.

Lifford (1985) noted that in Indonesia, pump irrigation schemes failed to attract the rural poor because the development agents were more concerned with achieving objectives of the donor (Dutch), at the expense of the intended beneficiaries. Thomas 1999 refers to this scenario as management of development as opposed to management for development. To the beneficiaries, the irrigation schemes were meant to benefit the chairperson, his committee and friends, since there were the ones in touch and involved in the planning process with development agents. Lifford (1985), further noted that although the key model of reducing poverty through irrigation farming was 'community participation' and learning by doing; this was taken lightly since development agents believed lack of knowledge and ignorance among the villagers would delay the attainment of donor objectives.

The Zimbabwe government had an ample time in trying collectivization in the last 3 decades, but most programmes and projects on this line have not been successful. The model B cooperative type is a case worth noting $^{4}$

From this theoretical framework it is worth noting that development models, created by external agents and agencies, without consultation, involvement and participation in decision making of the intended beneficiaries are bound to fail. Was therefore command agriculture worth pursuing, taking into account local knowledge and needs in irrigation farming in Makwe irrigation scheme?

\section{Maguta Rhetoric}

Operation Maguta is a national programme and hence different people view it differently. Literature reviewed reveal that it had become a norm in government circles to refer to any aggressive policy as an "operation", for instance operation 'murambatsvina' and 'garikai'. Besides the adverse report by the parliamentary port folio committee on land, land reform and resettlement most pro government cronies and academics painted a glorious picture of the whole operation. Gono, Governor of the Reserve Bank of Zimbabwe when addressing participants in a military course in Harare noted that:

"We applaud the Zimbabwe Defence Forces for taking up the challenge by strapping their guns on their backs and rolling up their sleeves to till the land under operation Maguta. Under this programme, no doubt a huge food gap will be closed, effectively saving foreign exchange to go towards other priority sectors of the economy".

In August, 2006, the minister of State security, Lands, Land Reform and Resettlement declared that resettled farmers were compelled to produce crops such as grain on a portion of their land. He emphasized the issue of growing strategic crops such as grain. "This is important because it guarantees food security so that we do not suffer from hunger that we sometimes suffer from ". ${ }^{\circ}$ In the case of dry regions like Matabeleland South the minister stated that A1 and A2 beneficiaries should sell a certain number of their herd to government. Agriculture minister said personnel from the army, air force and police have been enlisted to take charge of food security by producing the staple maize and other key grains while taking over the harvesting and distribution of key crops. He noted that the armed forces were in the farming season 2006/07 to plant 300000 hectares of grain. "Defence forces are not out there to cause problems."... "We want all (government) departments to cooperate and other civilians to pick skills and knowledge imparted by them. We want their brains and resources" "In the mean time by that time the State controlled Grain Marketing Board headed by a Retired Colonel was struggling to collect maize from rural farmers. Another group of pro state command agriculture proponents the Zimbabwe Farmers Union through its president echoed the complimentary role the army was playing in an effort to resuscitate agriculture by noting that; "this will not only guarantee food security but is also meant to consolidate the government's land reform programme" (Reuters, 2006). As late as October 23, 2006, the Chief Executive of the Zimbabwe Chamber of Commerce praised the defence forces for the success of Operation Maguta and so was the president of the Confederation of Industries who lamented; "we in the private sector, are solidly behind the operation and its success

\footnotetext{
${ }^{4}$. Model B, This was an intensive settlement with communal living and cooperative farming. All property, land and equipment were cooperatively held, housing could be cooperative or private, and livestock was privately owned. Most of the farms had sophisticated irrigation equipment and farming equipment. Many original cooperators deserted the schemes. This model failed.

${ }^{5}$ The Chronicle, 1 March 2006. "Grain imports gobble US\$131 million. Governor Gono addressing Zimbabwe Defence forces Joint Command staff course participants.

${ }^{6}$ The Herald,18 August, 2006; Minister Mutasa

7 ABC Online quoting Made in the Herald, 26 September, 2006
} 
On the other side, the independent, in August, 2006 carried a headline; 'Operation Maguta suffers set back'. The content of the report revealed that agricultural production through operation Maguta was failing as the area under winter wheat over the past five years continued to shrink. It went further to give statistics and noted that the army had managed to put under irrigation only 20000 hectares under winter wheat. The Vice President comrade Joyce Mujuru was quoted in the Herald of 2 November 2006 crying foul of beneficiaries of the Land Reform Programme for disgracing the government by failing to effectively utilize allocated land..

Those writing from the left school of thought believed by engaging the army in agricultural development the notion of food security would be attained speedily. They felt the army could fill in the gap created by non producing land occupiers. While those from the right believed the involvement of the army was bound to destroy agricultural development, thus jeopardizing the attainment of food security goals. They believed the introduction of the army is to fill the gap created by allocating land to people without farming skills; let alone the appetite of farming. Both proponents of these opposing schools seem to be concerned with broad macro goals and objectives of the state, but the rhetoric does not address the issue of particular communities, like Makwe who were directly affected by the operation. Verdery (2003:161) in her ethnography, The Vanishing Hectare; in Romania and other former Eastern Bloc countries cites Humphrey (1998:270); "Collectivization had completely transformed kinship patterns in rural areas, undermining the authority of elders. Wealth ceased to be primarily a matter of inheritance, and households' patriarchs no longer organized labour of their units- the collectives did that". In this research the irrigation committee had been dissolved, individual time schedules for work apportionment at the plots and other social obligations had been affected by the command of soldiers as indicated below.

\section{Makwe irrigation scheme and its activities.}

Makwe irrigation scheme was established in 1968 under the drought recovery scheme known as the Tribal Trust Land Cooperation (TTLCO). The Rhodesia government constructed Thuli-Makwe Dam, which locals' call "Haliwulu" The regime set up this irrigation scheme having observed the vulnerability of the surrounding communities of Wenlock to drought. It was believed that this irrigation scheme will not only produce crops or food for the plot holders; but surplus was to be sold to the aforementioned areas at nominal prices Chiefs were asked to identify 'master farmers' in their areas, who were then allocated plots and worked directly under the supervision and management of (TTLCO). TTLCO gave plot holders inputs, such as fertilizers, seeds, insecticides; and in the early days cleared their land. These inputs were a loan which was payable after harvest. According Bango, a retired Agricultural Demonstrator who is also a current plot holder, this system worked well for the farmers and assured them of inputs timeously for the next crop. ${ }^{8}$ Vegetable growing was not funded, so plot holders bought their own seeds and inputs for market gardening. (See also The Solidarity Peace Trust 2006).

After independence in 1980, the same tenants remained in the scheme; and additional plot holders were brought in when the irrigation scheme was extended to cover 60 hectares and currently is 202 hectares with 360 irrigators. This time Chiefs, assisted by AGRITEX Extension Workers identified competent 'master farmers' in adjacent Wenlock communal area to join the scheme. According to the irrigation committee chairperson, each plot holder is allocated a half a hectare in the scheme. In liaison with the District council; a plot holder is automatically guaranteed a homestead stand in Makwe village. It should be noted that the permits allowed deceased plot holder's descendants to inherit the plot. However if the dependants fail to utilize the plot the committee had a right to retrieve the plot and re- allocate to another master farmer ${ }^{9}$

In terms of land preparation, it was the duty of each individual plot holder to organize; in most instances plot holders assisted each other with draught power; for instance rotating ox-spans on a daily basis among a selected group of individuals so as to meet the planting deadline. Some hired a tractor from Zwelitsha Nyathi a local building contractor and plot holder. Nyathi would at times allow those without cash to pay in kind after their harvest. Mancube an irrigator had this to say:

"Before soldiers came we helped each other in ploughing our plots (amasimu).We arranged ourselves in groups, purely on individual understanding to rotate our spans of oxen It was our own initiative as we had done this over the years. We are not the same in terms of draught power, some have oxen some do not have. Some have money to hire tractor from Nyathi some do not have. But all in all no one failed to meet the planting deadline of any crop as given to us by agricultural extension workers. Fertilizer and seed we bought on our own as individuals, and at times the irrigation committee will organize for us so that we give them money and they buy from Bulawayo and just pay transport. Abalimisi teach us how to plant, cultivate and manage all the crops and vegetables we grow here."

\footnotetext{
${ }^{8}$ Job Bango is a retired Agricultural demonstrator whom I interviewed at his home in Makwe village. He worked for DEVAG and then AGRITEX after independence. In all he worked in this scheme for over 30 years.

${ }^{9}$ Interview with Nicholas Nkala irrigation Chairperson (20/12/2005).

${ }^{10}$ Abalimisi are AREX Officers. Who understood when plot holders told them of rituals to be performed before planting any crops?
} 
The role of Agricultural Extension workers; two of them is to give technical advise on best farming practices. A committee of ten which ran the affairs of the scheme planned crop rotation and used to liaise with farm inputs suppliers for bulk purchases of inputs such as maize, wheat seeds and fertilizers. Plot holders paid for electricity and water to the relevant departments quarterly. Each member, over and above contributing to the electricity and water bills paid ten dollars as a monthly subscription for being a plot holder. Before the arrival of soldiers, Makwe plot holders had a seasonal calendar for major crops; from February to April, they had sugar beans on the scheme, May to August winter wheat and September to December it was time for maize. During these periods as the chairperson of the irrigation scheme explained; plot holders could sell green beans and maize to supplement their income. In addition to the main crops plot holders planted a variety of horticultural crops which catered for the day to day consumption of households. Surplus horticultural produce was sold to markets in Bulawayo, and vegetable vendors from Gwanda town also came to order for resale.

\section{Arrival of Soldiers and operation Maguta in Makwe.}

From a national perspective, command agriculture was first announced by the reserve bank governor in May 2005 when he presented his quarterly monetary policy statement. "Command agriculture seeks to optimize output by requiring a minimum input for food or export crops, and is central to agriculture as well as general economic recovery. ${ }^{11}$ The government's command agriculture model intended to place 1,5 million hectares under maize production in the 2005/06 farming season and produce 2,2million tones of maize. ${ }^{12}$ The Command Agriculture Joint Operation Command had projected a budget of Z $\$ 15$ trillion (Z $\$ 15$ billion revalued), but by November 2005, the Parliamentary Portfolio Committee on Lands, Land Reform and Resettlement, reported that government has failed to raise the money; and hence command agriculture was referred to in the same Parliamentary Committee report as " noble on paper (but) a stillbirth ${ }^{13}$

In late November the soldiers finally arrived at Makwe irrigation Scheme around ten o'clock in the morning, they called a spontaneous meeting with the community and explained their mission. The chairman narrated the story as follows:

"They arrived around ten o'clock in the morning and came straight to my homestead but unfortunately I was busy in the plot, so they remained in the business centre and sent my wife to fetch me. When I arrived, they shouted at me and said they are giving me 15 minutes to call a meeting for all irrigators. When the meeting finally took off, a colonel introduced himself and his team of 20 soldiers. He told us that as from now on we will not be allowed to grow anything in this irrigation except maize and wheat. The Colonel announced that by the time he comes back all existing structures in the scheme have to go as he will take charge of the operation himself. We were not given a chance to ask questions. "14

The next encounter with the soldiers was on the $14^{\text {th }}$ December 2005, and I was lucky to witness the whole event of the day. It was around 12 o'clock in the afternoon when a Bedford truck full of soldiers descended on Makwe irrigation. As prior arranged; the soldiers had penciled a meeting for 9 o'clock in the morning but only arrived mid day. The meeting started and the same colonel addressed it. He noted that people did not take heed of what he instructed them to do when he came in November, and boastfully asked the meeting what he had instructed them to do; when everybody kept quite, he off the cuff scolded the chairperson and told the meeting that his role as chairman is no more, calling him all sorts of bad names. He eventually told the meeting that tractors were on their way to prepare land for planting maize;

"I am telling you that the tractors are just about to arrive, and when they arrive everybody should run to meet them in the fields and more talk will be done there ${ }^{, 15}$

When the tractors finally arrived we all went to the fields and here the bad thing started happening; men and women were forced to uproot Banana trees and some fruit trees. There was a huge crop of vegetables, cabbages, carrots, spinach, sweet potatoes, pepper, paprika; all that was to be history in a few hours time. District Development Fund tractor drivers were commanded military style to commence ploughing the fields, and that was the end of market gardening in Makwe. The plot holders were advised by the same colonel " by tomorrow everybody must plant and finish his or her portion and if you are not through don't go to sleep...do you get me"; people just kept quite and that was the end of the $14^{\text {th }}$ December 2005.

What did this arrival bring to the plot holders in Makwe? Firstly when the soldiers came already the plot holders had planted their maize section as usual, and by their seasonal calendar the maize was already tussling since they normally sell green maize during Christmas and New Year holidays and harvest in late January to early February so as to prepare for planting sugar beans as from mid February. Plot holders were not

\footnotetext{
${ }^{11}$ Zimbabwe independent 18-24 November 2005; was citing Gono the Reserve Bank Governor when he presented his monetary policy statement in May 2005.

${ }_{12}^{12}$ Zimbabwe independent 18-24/11/2005. 60\% of Agricultural funds disappear.

${ }^{13}$ Zimbabwe independent 18-24/11/2005

${ }^{14}$ Chairperson of Makwe irrigation scheme, explaining their first encounters with the soldiers...interviewed on 20 December 2005.

15 ZNA Colonel on the $14^{\text {th }}$ December 2005 when implementing the operation.
} 
allowed to take maize for their domestic consumption without permission from the soldiers. When ever permission was granted; the plot holder was supposed to inform the base commander the number of family members; and the plot holder was then allowed to take the exact number of combs, i.e. one per household member. Those who did not finish planting the area ploughed by DDF tractors were severely punished. When I interviewed some irrigators they revealed to me that a lot of people who did not complete ploughing as per instruction were severely beaten, some had to be hospitalized. Nkala, the irrigation chairperson was summoned to the "Regional", where soldiers had established their base; to answer charges of questioning the wisdom of asking people to work at night since according to Ndebele culture working in the fields at night is taboo. They equate it with witchcraft. When the Chairperson arrived, with other four members of his committee they found soldiers having a nice time with uprooted sweet potatoes, and there was a heap of cabbages of which they believed soldiers were to take to Gwanda town. During the destruction of market gardening plot holders were not allowed to take anything from the irrigation. The five irrigators were severely assaulted by soldiers and commanded to fetch water and fire wood for the soldiers after a thorough beating. ${ }^{16}$

The ex-agricultural extension worker, Bango later on in January said that, the way planting was done under the command of the soldiers will have a negative effect on the future fertility of the soil in the irrigation. He related a chronological way of farming in the irrigation:

"Planting irrigable maize does not involve just ploughing and planting; you need to plough, prepare and level the field, prepare furrows, apply fertilizer and then plant your maize. This whole job cannot be done one day; you need two to three days to complete it. The soldiers also applied huge quantities of fertilizer, and by agronomy standards, that amount will render the soil infertile in the next season."

To Bango the soldiers have destroyed their source of livelihood, let alone their commons. Gudeman (2001:27) notes that the commons is a shared interest or value. It is the patrimony or legacy of a community and refers to anything that contributes to the material and social sustenance of a people with a shared identity: land, buildings, seed stock, knowledge and practices, a transportation network, an educational system, or rituals...Without a commons, there is no community; and without a community, there is no commons"

Maketsi Mdlongwa is one of the informants I interviewed after the introduction of this command agriculture; Maketsi was at pains about the whole programme:

"This maguta operation has destroyed our way of life in this village, we used to sell vegetables on a weekly basis to markets in Bulawayo but now there is nothing to sell. We used money from proceeds of the irrigation to send our children to school. I have relatives in Wenlock and as you know that there was drought for many years, I supported them from what ever I got from this small plot of mine. I am not formally employed and depend mostly on this irrigation plot which I inherited from my father. I do not know how we will survive by growing maize and wheat alone. The soldiers told us that our crop will be bought only by the Grain Marketing Board and were warned not to attempt to sell to outsiders or provide our relatives in the communal land. Before this 'Maguta', we did not sell everything to GMB; we decided on the quantity to sell and that for our consumption. Now everything has to go."

The other informants also echoed the same sentiments as Maketsi. It is apparent from the findings from this field work that soldiers and their operation have brought untold suffering to the Makwe community. Income generating projects which were down stream activities of cash crops and market gardening collapsed. One woman informant told me that they suspended their money link club because of lack of income. They used to give each other Z $\$$ I million dollars every two weeks, and there were ten of them, on rotational basis. This liquid cash assisted members' households in buying household goods and other non food items necessary for their survival. The Makwe community really survived on this land; and soldiers interfered in their way of life.

\section{Impact of command agriculture and its effects on the way of life of Makwe villagers}

Nationalization of agricultural land can be viewed as a retrogressive policy. In Eastern Europe communist parties' nationalized land, but what befell them in 1989 is testimony of the implications of such an economy in contemporary society. Verdery 2003, acknowledged Proudhon's claim that "Property is Theft"; and further noted that the greatest theft in history was the nationalization of assets in the Soviet Union; including all its land, which was turned into collectives and state farms. Verdery (2003) further noted that...for the builder of socialism, land in particular, was very valuable for several reasons. Socializing it would facilitate plans for rapid industrial growth by (1) seeing a major means of production and transferring its surplus directly into industrialization; (2) controlling the rural population, the supply of food and thereby determining the price of food and(3) creating a proletariat for industrial work (Verdery, 2003:41-42). Was therefore by launching operation Maguta, the government pushing a similar agenda as the failed communist/socialist states? Did the state want to control food for a particular agenda? These are macro issues which need to be verified. However to the Makwe community, command agriculture, completely cut off the main lifeline of these villagers as indicated

${ }^{16}$ Interview with chairperson and informants 1, 2, 3, and 4 17/01/06. Makwe village. 
in the case studies highlighted above. Ready income that had been trickling in to plot holders for over 4 decades had suddenly been cut off. It is worth noting from primary data that the coming in of soldiers to Makwe had not only affected the market economy of the plot holders, but has even thrown in spanners to the community economy. This is so because plot holders had their own structures, values and relationships as a community. For instance, to the Makwe community the chief had a strong say on cultural practices and on who gets the plot when, a particular household decides to leave the scheme.

Besides being traditional, Makwe villagers are Christians. It is a norm in this village that every meeting or gathering must be opened and closed with a word of prayer. When soldiers arrived they neither consulted the chief nor any formal structures. They did not observe the community norms, they took upon themselves to dictate what was to be done, how it was to be done, and when it was to be done which crops to grow and how produce was to be apportioned. The long standing committee which had its own constitution was uncaringly dismissed and soldiers went on the move. From a political and social perspective the irrigators were reminded of the doom days of the "Gukurahundi"; during this era soldiers closed the irrigation scheme, killed people and caused pandemonium in the village.

The introduction of operation Maguta also has had a negative impact on businesses operating at Makwe business centre. Without quick income from cash crops and market gardening, the buying power of plot holders has been severely eroded. One businessman I interviewed confirmed that his business had gone so low that he intended closing down. This had a negative impact on service provision to rural communities. Rural communities in adjacent areas of Wenlock have been indirectly affected by loss of affordable legumes and vegetables for their daily consumption. As alluded by Maketsi earlier own in this study; most, if not all plot holders in Makwe have kinsmen in these areas and support them in times of drought or when ever necessary since there are in dry natural region IV. There is also a feeling by residents of the irrigation scheme and adjacent villages that government has been unfair to them in recent years. The councilor who is a ruling party cadre also complained about the operation, though not being against it; but was not happy about the uprooting of vegetables as she noted:

'This is very unfair to us who have provided seeds, fertilizer and labour to make this irrigation a success story; my colleauques in council were also disturbed when I told them that the orchard that had been visited by both local and international aid agencies as a model project was no more. I feel government should do something, otherwise we will get no votes from this village".

Sara Berry (1993:13) notes that, in rethinking African Agrarian change, we need to begin with historical and anthropological literature which represents law as social process, transactions as subject to multiple meanings; and exchange as open ended and multi- dimensional rather than single stranded and definitive. I argue that if we are to bring about agrarian change, there must be synergy of power, economy and culture. In the Makwe case, soldiers wielded power and the economy of Makwe plot holders rested on them. The chief as the custodian of their tradition was never consulted; hence cultural rituals, values and norms were overlooked by the soldiers. What does it mean to a Makwe villager working until 12 mid night in the fields? What does it mean to the poor plot holder to work the fields on Wednesday, their sacred day (Izilo) ${ }^{17}$ What does it mean to the plot holder who has had the prerogative to choose what to sell and what to keep for his/her family and kinsmen for 40 years, to beg soldiers to access 500 combs of maize? The answers to these questions indicate how shocked and deprived Makwe villagers have been by operation Maguta.

I further argue that failure to respect cultural dynamics of a community leads to failure of any innovation one might want to introduce. In the Ndebele tradition, there are certain rituals to be performed before any new crops are planted; for instance maize seed is mixed with herbs only known to a chosen few in the village and then a specific day of planting is agreed on by the elders who will plant just a few rows and then everyone is safe to plant. Without this ritual it is alleged that crops may be destroyed by wild animals. Berry citing the World Bank (1989), contend that rural development programmes in Africa rarely work the way they are supposed to. Since independence, International agencies and African governments have initiated hundreds of programmes designed to accelerate agricultural growth and/or raise rural living standards; with a few exceptions that achievements of rural development policies and projects have fallen short of expectations or turned out opposite what was intended. Why is it like that? Berry further argued that development policies are economically inappropriate, because politicians are more concerned with staying in power rather than promoting economic growth (Berry 1993:44).

Makwe irrigation scheme as explained earlier own was run by the Department of Agricultural Research and Extension services (AREX) prior to the inception of operation Maguta. The scheme has two full time Agricultural Extension Workers who are employed by government. These two officers have been sidelined by

\footnotetext{
${ }^{17}$ Izilo is a Ndebele word which in this text refers to Wednesday as a sacred day whereby no one is allowed to work the fields. It is believed that if any member of the community works the fields on that day; traditional gods and spirits can cause misfortunes like drought or cyclones.
} 
the soldiers. As I highlighted in the previous section, agricultural competency of the soldiers is questionable as evidenced by the excessive application of fertilizer of which the former agricultural demonstrator alluded to.

The coming in of soldiers has also created a situation of uncertainty among the plot holders. They used to plan for their inputs according to their seasonal calendar, that is; maize-by August they made sure that they were ready; sugar beans- by January,; and by April they made sure that inputs for winter wheat were ready. These inputs were either sourced as a group through the irrigation committee or individually ${ }^{18}$ However with the new policy; they were not certain whether the army would meet the target dates as evidenced by delays in supplying inputs for winter wheat in the 2006 planting season.

From evidence of my fieldwork, Makwe irrigation scheme was now underutilized. The argument is that the scheme was effectively utilized for a period of seven month as they grow only two crops; maize and winter wheat. Prior to the operation, the scheme had crops all year round since they would in addition to cereals engage in market gardening. The same sentiment of under utilization of irrigation schemes was echoed by the Agricultural Extension Worker in Umzingwane district when I conducted research in Kondwane A2 farms in May 2006. The Extension Worker noted that, "the purpose of community irrigation schemes from an agricultural point of view is not growing staple food only, but also growing cash crops that could earn fast income for the day to day welfare of the household. Irrigations should boost nutrition levels of household members". ${ }^{19}$

Command agriculture moved the Makwe community closer to socialist oriented agriculture whereby land was owned collectively. For instance in this new scenario plot holders instead of planting their own Half hectares were now commanded by soldiers to plant the irrigation scheme not their individual plots. In Romania for instance when Socialist agriculture was in its last days there was rampant looting of state or cooperative property as members became discontented with what they felt was exploitation by the state machinery. In explaining the relationship between administration and use, Gluckman (cited in Verdery, 2003) distinguishes between estates of administration and estates of production (1965:89-93). Superiors hold estates of Administration, allocating rights downward, whereas those at the base holds estates of production, using the rights granted them to fructify collective assets. This citation by Gluckman can be equated with the state of affairs in Makwe where Soldiers were the estate of administration and the plot holders were the estate of production. The soldiers did not physically work the fields; they administered the production process. As noted earlier on, this state of affairs had repercussions towards the demise of socialism as a mode of production in former socialist states in Eastern Europe. In this instance Verdery notes that; two years before 1989...the holders of estates of production ceased to respect the hierarchy of command and began to usurp the state's rights of ownership.

\section{Conclusion}

Do the people of Makwe have to suffer for the problems bedeviling their country like Indian villagers who were displaced by the construction of the giant Hirakud Dam? Makwe irrigators did not ask for government intervention in the production process as it has been debated in this article. Government had already provided what they needed-technical and extension advice from the two extension workers. The operation had taken away the sense of ownership of the plots as the irrigators farmed the irrigation rather than their plots in the irrigation scheme. The old order whereby irrigators with the advice of Agricultural Extension Workers had a seasonal plan for utilizing the irrigation was history. The harassment by soldiers had led to the Makwe and surrounding villagers feeling that they are being punished by government. This has created a sense of fear and mistrust of soldiers. Fieldwork showed that since 1980, these villagers' encounters with soldiers has never been a pleasant one, maybe further research on the relationship of the army with communities in this region needs to be done.

Makwe plot holders' intra and inter social relationships and networks have been seriously affected. For instance, Wenlock residents who are not just psychologically connected to the villagers in Makwe, but also deeply socially connected, were no longer benefiting from the only irrigation scheme in their communal land. To the irrigation land, a base for plot holders, had been affected by the excessive application of fertilizer by the soldiers, and has destroyed its fertility. Command agriculture has brought shocks and stresses not only to Makwe irrigators but the whole community around, business persons inclusive, which used to benefit directly and indirectly from activities carried out in this scheme. From the debates in this article it is worth noting that command agriculture was an alien concept to the Makwe community. It had brought untold suffering to this community which had its particular ways of farming the irrigation through advice from experienced agriculturists. The Makwe community since independence, its interface with soldiers has been that of intimidation and torture. This has brought a sense of dispossession, and for sure as debated, they no longer owned their private plots in this irrigation scheme. Command agriculture can be viewed as forced

\footnotetext{
${ }^{18}$ Information given by interviewed plot holders (December 2005- May 2006).

19 Interview with the AREX Worker and member of the District Land Committee Umzingwane District May 2006.
} 
modernization, whereby the irrigators have been deprived of their sources of livelihood and forced to practice agriculture the way the state felt would salvage it from the economic hardships and tame food insecurity.

I therefore challenge the responsible authorities to let communal irrigation schemes operate under the guidance and advice of the department of Agricultural Research and Extension Services. If soldiers are to be involved in food security programmes and projects; I challenge the authorities to allocate under utilized A2 farms to these cadres so that they can start irrigation schemes. I take this stance because research in Matabeleland South has shown that the up take of acquired A2 farms is at most 30\%; and utilization levels are placed at below $20 \% .^{20}$ The state should be aware and clear that the top down approach to rural development does not work in contemporary development discourses. Command agriculture as an external rural development model is bound to fail if people's customs, norms and beliefs are sidelined in planning better programmes.

I therefore conclude by noting that Command Agriculture "Operation Maguta" should be redefined, redesigned and re-focused if the authorities believe is a noble policy; and probably re-directed to under utilized land in A2 farms rather than disturbing organized irrigation schemes. In organized irrigation schemes like Makwe, people have been surviving on this land.

\section{References:}

[1]. Berry. S. (1993), No Condition is Permanent. The Social dynamics of agrarian change in Sub-Saharan Africa. University of Wisconsin Press. Madison. Wisconsin

[2]. Catholic Commission for Justice and Peace (1999). Man in the Middle: Torture, resettlement and Eviction and Civil War in Rhodesia. Institute for International Relations.

[3]. Catholic Commission for Justice and Peace: Breaking the Silence, Building True Peace. A report on the disturbances in Matabeleland and Midlands, 1980-1989

[4]. Chambers, R. (1983). Rural Development: Putting the Last First, UK: Longman Group.

[5]. Chaumba. J.I. Scoones and W. Wolmer (2003). New politics, new livelihoods, Agrarian change in Zimbabwe. In review of African Political Economy, No. 98. 585-608.

[6]. Cormac, O. (1989). The Great Irish Famine: Gill and Macmillan. London

[7]. Donham D (1990) History, Power, Ideology. Central issues in Marxism and Anthropology. University of California Press. Wisconsin.

[8]. Donham D (1999) Marxist Modern. An Ethnographic history of the Ethiopian Revolution. University of California Press. Berkeley.

[9]. Fairhead, J (1993) 'Representing Knowledge: the new farmer in research fashions, in Practising Development: Social Science Perspectives, Pottier, J (Ed), London and New York: Routledge

[10]. Frydman, R and Rapaczynski, A. (1994). Privatisation in Eastern Europe. Oxford University Press. Oxford

[11]. Harris, John. (1982). General Introduction in Rural Development: Theories of Peasant Economy and Agrarian Change. Hutchinson University Library: London.

[12]. Gudeman S (2001). The Anthropology of Economy. Community, Market and Culture. Blackwell publishers, Massachusetts.

[13]. Strategy, Autonomy, Class Bias and Economic Rationality. Zimbabwe Institute of Development Studies, Harare.

[14]. Lifford...(1985

[15]. Rodney, W. (1972): How Europe underdeveloped Africa. Howard University Press, Washington, D.C

[16]. Solidarity Peace Trust (2006). Command Agriculture in Zimbabwe: its impact on rural communities in Matabeleland; accessed on; www.solidaritypeacetrust.org

[17]. Thomas, A. (1999). What Makes Good Development Management? Development in Practice, Vol, 9: 9-17

[18]. Verdery K (2003). The Vanishing Hectare. Property and Value in Post Socialist Transylvania. Cornell University Press, London.

[19]. Thomas, A. (1999)

[20]. News paper articles/press releases.

[21]. The Chronicle, 1 March, 2006

[22]. The Herald, 2 November, 2006

[23]. The Herald, 18 August, 2006

[24]. The Herald 4 November, 2006: Mujuru disappointed by land reform beneficiaries.

[25]. The Zimbabwe Independent, 18-24 November, 2006

[26]. The Zimbabwe Independent, 15 August, 2006, operation Maguta suffers setback.

[27]. ABC online, Zimbabwe security agents take over food security; accessed on 16/10/2006, on www.abc.net.au

[28]. Zimbabwe Government (1984)-First Five Development Plan, Vol 2, 1984

${ }^{20}$ Provincial land officer Matabeleland South province, statistics of provincial uptake and utilization of A2 farms, April 2006. 